Article

\title{
Human Relationships with Domestic and Other Animals: One Health, One Welfare, One Biology
}

\author{
Ariel M Tarazona ${ }^{1, *}$, Maria C Ceballos ${ }^{2,3}$ and Donald M Broom ${ }^{4}[$ \\ 1 Facultad de Ciencias Agrarias, Departamento de Producción Animal Medellín, Universidad Nacional \\ de Colombia, Antioquia 050034, Colombia \\ 2 Grupo ETCO, Group of Studies and Research in Animal Ethology and Ecology, Jaboticabal-SP 14884-900, \\ Brazil; mceballos30@gmail.com \\ 3 Swine Teaching and Research Center, Department of Clinical Studies, New Bolton Center, School of \\ Veterinary Medicine, University of Pennsylvania, Kennett Square, PA 19348, USA \\ 4 St Catharine's College and Department of Veterinary Medicine, University of Cambridge, Madingley Road, \\ Cambridge CB3 0ES, UK; dmb16@cam.ac.uk \\ * Correspondence: amtarazonam@unal.edu.co
}

Received: 29 October 2019; Accepted: 20 December 2019; Published: 24 December 2019

Simple Summary: In a situation where human actions are damaging much of the life of the world, it is important to remember that the basic concepts of biology, welfare, and health are the same for humans and all other animals. Human actions have wide consequences and we need to change the way we interact with other living beings. An understanding of the concepts of one health, one welfare, one biology, and their application to daily decisions about production systems, public policies, markets, and consumers could mitigate current negative impacts. In particular, an understanding of human relationships with animals used for food, work, or company helps in dealing with challenges concerning their use and system sustainability, including the animal's welfare. Animal welfare should always be considered in our relationships with animals, not only for direct impacts, e.g., manipulations, but also for indirect effects, e.g., on the environment, disease spread, natural resource availability, culture, and society.

\begin{abstract}
Excessive human population growth, uncontrolled use of natural resources, including deforestation, mining, wasteful systems, biodiversity reduction by agriculture, and damaging climate change affect the existence of all animals, including humans. This discussion is now urgent and people are rethinking their links with the animals we use for clothing, food, work, companionship, entertainment, and research. The concepts of one health, one welfare, and one biology are discussed as a background to driving global change. Nothing should be exploited without considering the ethics of the action and the consequences. This review concerns domesticated animals, including those used for human consumption of meat, eggs, and milk; horses kept for work; and dogs kept for company. Animal welfare includes health, emotional state, and comfort while moving and resting, and is affected by possibilities to show behavior and relationships with others of the same species or with humans. We show some examples of the relations between humans and domesticated animals in the environmental context, including zoonotic diseases, and consider the consequences and the new paradigms resulting from current awareness.
\end{abstract}

Keywords: animal welfare; animal behavior; sentience; zoonoses; sustainability 


\section{Introduction}

\subsection{Who Are We?}

From a biological point of view, each human is an animal, a mammal, an ape with a scientific name like other animals Homo sapiens [1]. Many studies have shown that humans are different from other animals only in degree, not in terms of the general aspects of the biological functioning of their genome, body, or brain. There are differences in the way that human and other brains work, but humans share each of the brain systems with many other animals [2-5]. Whilst there are differences in the anatomical areas in which functional mechanisms occur, the actual functions that occur in humans also occur in other species. For example, the high-level cognitive functioning of birds like crows and parrots occurs in a different anatomical area from that in mammals, and pain analysis occurs in different areas in different groups of fish and in mammals. The human frontal and pre-frontal cortex have some more complex activities compared with other animals. Humans have better mathematical logic, perception of time, complex reasoning, analytical capacity, and prediction of events than most other species [6]. However, many non-human animals use their brains to make complex decisions, plan for the future, have concepts of objects that are not present, use tools, communicate, deceive, and show empathy [4]. Examples of empathy include a chimpanzee responding to another during childbirth, a dolphin lifting a human swimmer in difficulty or a sick dolphin, and a pet dog responding to another individual that is in pain; some of these are shown in [7-9]. The basic concepts of biology are the same for humans and other species and almost all biological systems occur in all vertebrates, including humans, so if each human is considered important, each other vertebrate individual could reasonably be considered to be important [10]. Contrary to the teachings of some religions, humans are animals; they have few differences from other animals and do not have to be considered as special in the sense of being more important [11]. The logical question raised here concerns how great a difference between one species and others requires that the species be valued more, or valued so much that other species are hardly valued at all. Humans can do much harm to other animals and to the local and world environment.

Thanks to advances in knowledge of biological phenomena related to reproduction, we know that animals with sexual reproduction (including humans) come from the DNA contained in an ovule (maternal) and a spermatozoon (paternal), producing the genotype that interacts with the environment to result in the phenotype of the new individual [12]. The probability of each individual existing is very low. Each human comes from one spermatozoon out of approximately 200 million [13], that merges with one of approximately 300 thousand potential ovules [14]. To this, we add the improbability that the parents of that individual existed, and also their grandparents, great grandparents, and so on, for generations. Every cow (Bos taurus, B. indicus), pig (Sus scrofa), dog (Canis familiaris, C. lupus), cat (Felis sylvestris catus), rainbow trout (Onchorhynchus mykiss), horse (Equus caballus), and human share this improbability in general terms. Being aware of the improbability of life, its short duration and its fragility, we could assign more value to and have more respect for other equally improbable life forms. When making use of animals for food, work, or companionship, we could consider that each is a unique and unrepeatable life.

During human evolution, there have been specialist developments, such as the thumb becoming opposed to the other fingers and the brain structure that allows grammar in language [15]. Other kinds of animals developed other specializations that are different adaptations from those of humans, not worse adaptations. Humans developed physical abilities to make things and a complex brain. Is this the ultimate that is possible? Future beings are likely to have greater abilities and current human abilities are already in some ways surpassed by the robots and other machines that are created by humans to replace us in many daily tasks [16]. A key adaptation in humans and other animals has been the evolution of feelings and emotions such as fear, anger, pleasure, and pain that facilitate learning and other components of environmental control systems $[17,18]$

Humans are more similar to other animals than most people think. The DNA of all vertebrates including humans has far more similarities across groups than differences [19]. The differences that some people present as exclusive to humans, such as language, emotions, the notion of culture or society, 
cooperation and altruism, have been reported in other beings, with scientific evidence demonstrating their existence in various groups of animals [4,10]. Indeed, some non-human species can be considered as moral agents $[3,11]$. In addition to our production of elaborate artistic outputs, two qualities that we might not share with non-human animals are that we produce much non-organic waste and we have the potential to decide more about our diet and environmental impact. An answer to the question "Who are we" is that we are the sentient beings living on earth.

As mentioned above, there is only one biology and all of the basic concepts, including welfare and health, have the same meaning for all animals. The concept of welfare as defined by Broom in 1986: "the welfare of an individual is its state as regards its attempts to cope with its environment" [20], includes feelings, health, and other mechanisms for coping. It clearly applies to humans and to any other living animal. Health is an important part of welfare and is the state of an individual, as regards its attempts to cope with pathology [21].

\subsection{Where Are We?}

Despite the wide-ranging effects of humans during 200,000 years and recent loudly-voiced campaigns for resource conservation, the reduction of waste, and the responsibility of each person for the care of the planet, little has actually been achieved to stop us from being one more species within the 6th great extinction [22,23]. In a universe 13,700 million years old, on a planet 4,500 million years old [24], our species is very young compared with jellyfish 500 million years old [25] or cockroaches 350 million [26]. Only in the last 13,000 years have humans created substantial settlements and utilised many plant and animal species [27,28]. Domestication of species such as goats, sheep, pigs, cows, dogs, and cats [4,29,30] and the evolution of human-animal relationships [31,32] have been described. We consider here how we have modulated our relationships with animals, negatively and positively and the impacts of the sciences of ethology and animal welfare. The history of animal welfare science is discussed by Broom [4,33].

Humans have long seen the world as a pantry, as a warehouse of materials that could be exploited and used at will, as if they were infinite and as if there were no consequences of material extraction or use [34]. Energy from coal, steam, oil, and oil derivatives led to humans generating much non-organic waste. This can remain unchanged for decades, centuries, or perhaps millennia, generating unpredictable consequences for the integrity of the matrix of life on the planet [35]. As a consequence of the human actions of the last two centuries, we are currently facing climate change [36], emerging diseases derived from animal population management [37], environmental pollution [38], deforestation [39], loss of ecosystems due to mining [40], and loss of biodiversity on cultivated land because of herbicide use, pesticide use, and other agricultural practices [41,42]. The changes in our relationship with domestic animals, associated with the intensification of farming, has resulted in many animal welfare problems. In the last few decades, the public perception of consumption has changed and has generated demands for the creation of laws, codes of practice, and public policies for the improvement of animal welfare in many countries [4,43]. Currently, animal welfare has been accepted as a key issue by FAO and OIE, is a public morality issue accepted by WTO, and is an integral part of the sustainability criteria of animal production systems [41,44].

\subsection{Where Are We Going?}

There is currently increasing production of meat, milk, and eggs, as demanded by the growing human population. Industrialized systems require a large number of resources such as water, soil, fertilizers, and fuels [45-47] and the use of world resources is often inefficient. They generate significant amounts of waste such as faeces, urine, materials used as bedding, and by-products not used in human food such as bones, leather, feathers, and hair. In addition to the potential effect of waste, water and air pollution, products may also contain residues of medications or antibiotics and this is a significant problem to solve, for example because of their effect on native aquatic populations [48]. Some of these systems have negative consequences for aspects of sustainability, including animal welfare. However, since good welfare generally results in higher production efficiency, we must use systems with good 
welfare that optimize the use of resources such as water and soil, use alternative energies such as solar or wind, and generate less and cleaner waste.

Although currently there are many initiatives to change traditional industrialized systems to cleaner alternatives that use world resources better, the reality is that the human demand for animal protein, working animals, and companion animals far exceeds the rate of transformation of those systems. Given this situation, we present some of the challenges concerning the welfare of domesticated animals. The concepts of one health and one welfare [49] are becoming widely accepted and we add "one biology". The one biology concept implies that the biological principles are exactly the same for humans and all other animals, although there are specific differences between species and between individuals. Investigating biology means investigating humans together with all other species. Ecological, conservation, and other environmental principles should not be thought of in different ways in relation to humans and other species. Whilst different kinds of animals have different needs, the concept of health and the concept of welfare are exactly the same for a human, a pig, and an octopus (Octopus vulgaris). Consequently, decisions about relationships between humans, other animals, and the environment should respect all biological aspects of all living beings. No production system is isolated and devoid of impact on or consequences for the local and world environment. An interesting example of the relationships between disease, welfare, and socio-economic issues is presented by Thumbi et al. [50] This study, from sub-Saharan Africa, shows linkages between human and animal health, and the consequences of averting human disease for malnutrition, household educational attainment, and income levels [50]. New challenges arise regarding requirements for an animal production system, among them, the importance of the role of animal welfare in sustainability, the development of public policies and standards, precise methods of evaluation, and the importance of understanding animal welfare science in order to respond to these challenges [51].

\section{Current Trends in Animal Production Systems}

In the 1960s, a change in human perception of animal production systems involved considering inadequate animal housing and management in industrialized systems that cause pain and suffering to the animals. Publicity about this, and demands from the public and politicians for accurate information about the animals, unleashed a series of reactions that eventually led to the consolidation over time of animal welfare science. This provides knowledge concerning the needs of animals and scientific evidence about how well individuals are coping with their environment. Using this, we can provide each species of animal that we keep with the most appropriate housing and management conditions for their physical condition, mental state, emotional balance, and for appropriate expression of behaviors [52].

It has been recommended that animal welfare should be considered in relation to "quality of life" and "a life worth living" [53-55]. Quality of life means the same as welfare, although not normally used for short time periods, so can be measured [56]. The measures of welfare are objective. However, there is a difficulty with saying whether or not a life is worth living, as the decision about this involves subjective human judgement $[4,54,57]$. We consider that it is better to rely on objective measures such as health, body condition, physiological and behavioral measures of welfare, and understanding the needs of animals and the supply of resources. In order to be able to judge what are the key factors affecting the welfare of farm animals, we have to consider the systems used, some of their physical components, and interactions between humans and farm animals, as described in the following sections. Recent welfare research has increasingly focused, not just on negative effects but on positive welfare with conditions provided where negative experiences, such as isolation, pain, fear, stress, are minimized and the opportunities to have positive experiences, such as grooming, rest, play and affiliative behaviors, are provided [55-60]. The history and bases of animal welfare science have been addressed [33,61,62].

\section{Production Systems and Animal Welfare}

Industrialized high-density systems, for any of the farm species, have common characteristics associated with animal welfare problems, especially those associated with the supply of resources and 
management in relation to the needs of the animals [63]. Since the characteristics are specific to each species, age, breed, sex, size, etc., we list the characteristics and make a short description of the main problems in each species.

\section{Welfare Problems Due to The Supply of Resources}

The first resource is the place where animals live and the existing infrastructure. Facilities are essential because the animal interacts by direct contact with surfaces such as floors, walls, columns, and doors; this interaction can generate discomfort, lacerations, or increase the risk of behavioral problems or diseases. Insufficient space per animal is a very common problem for housed animals.

\subsection{Housing Design}

The quality of the floors of the facilities where the animals live for most of the time have a big effect on welfare, as do surfaces of paths where the animals move within the system, for example to milking, loading, unloading, crowding pen, or squeeze-chute. Ways in which characteristics such as material, nature of gaps in floors, drainage, roughness, slipperiness, and dirtiness can affect the welfare include: Physical damage to the animal's feet, discomfort, inadequate rest postures, or difficulty in moving; discomfort during rest due to hardness of the floor, excessive wet or dirt; and increased risk of lameness disorders, respiratory infections, mastitis or endometritis due to dirtiness [64-67]. The materials of the walls may damage the animals, walls should be free of irregularities and elements that could potentially cause injury such as wire, ties, nails, screws, metal projections, or wood clips [68]. The animal may use the walls as a thermoregulation mechanism by heat exchange through direct contact so good building materials are essential for the maintenance of good welfare. The material of the roof can affect conduction of heat from the outside to the interior of the building [69] and alter the microenvironment in which animals live [70]. When not properly maintained, rodents or birds nesting under the roof are potential vectors of pathogenic microorganisms or parasites for both domestic animals and humans.

The building structures, and other components of the environment provided for domestic animals, interact with the weather in the region to produce microenvironment conditions for the animals [71]. Specialized equipment may generate or control wind, cold, heat, humidity, or other conditions. Ventilation is essential in buildings and vehicles for both thermoregulation and dissipation of aversive odors and harmful gases. Light is important because it allows many of the animals' natural behaviors; for example, in mares and sows, it is crucial for reproduction [72]. Temperature control is vital for homeostasis, and its absence can lead to thermal stress and sometimes parasite and disease proliferation. A small decrease in temperature can favor respiratory diseases, especially in juvenile animals. Thermal sensation is a consequence of temperature and humidity acting together. This perception by the animals is vital to avoid stress from both hyperthermia and hypothermia. Excessive air moisture decreases the rate of sweating and makes it difficult to exchange heat with the environment, and may cause heat shock in animals [73]. Solar radiation is essential in systems where animals live outdoors, not only in extensive systems but also in intensive confinement systems without shade. Excessive radiation in non-adapted animals can cause skin burns and has been associated with some types of dermal carcinomas, especially in depigmented animals [74]. The lack of shade can also cause heat stress [75].

\subsection{Food and Water}

Various studies in several animal species have shown that many characteristics of feeders and drinkers, such as material, size, height, and distribution, are important for animals. Inadequate designs and insufficient numbers of feeders and drinkers can generate serious welfare problems due to agonistic social behaviors or simply because they do not allow some individuals to access food and water resources [58]. Additionally, feeders with inadequate preventive maintenance can become pathogen sources. Damaged feeders and drinking troughs can increase the risk of injury to animals.

Food is a valuable resource for an animal that must meet three fundamental characteristics to avoid causing poor welfare. It must be provided in appropriate quantity, in good quality, and be 
accessible to all animals in a group. Therefore, factors such as the form of presentation of the food, the smell, color, taste, texture, and arrangement in space can determine whether or not all animals can access the resource when they have the motivation to do so [58]. Domestic species are willing to work hard to access water. Drinkers must be designed according to how animals show their water consumption behavior and be adapted to their anatomical structure. The water must be of sufficient quality to prevent problems in animals and be free of disturbing odors and tastes. The mishandling of both water and drinkers can generate many welfare problems due to dehydration; especially when the animal is under heat stress and its need for water increased. Any direct water consumption from natural water sources should take account of ecological implications. The amount of water used in beef production is described for four systems by Broom [47]

\subsection{Bedding and Objects in Animal Accommodation}

In many animal production systems, various materials are used as bedding in a building that houses animals. Among these materials are sawdust or wood chips, straw, synthetic materials, and agro-industry by-products such as rice hulls. The materials used in construction or bedding can also generate welfare problems, on the one hand for animal safety and on the other as a potential vector of diseases or parasites. Small particles forming dust can cause respiratory problems, for humans [76] but also for animals such as pigs and calves [77].

Objects in farm animal living accommodation can provide environmental enrichment to improve the captive environment and may prevent or reduce abnormal behaviors [78]. Objects can be fixed, mobile on the ground, or suspended, and designed to be touched, smelled, bitten or pushed. Objects within a system must be made of an innocuous material that does not injure the animals. Pigs prefer deformable and manipulable materials. Wooden objects can be dangerous when they break, leaving splinters that the animal can swallow. Plastic bags can cause asphyxiation and metal objects can cause cuts so all objects should be appropriate for the species.

\section{Welfare Problems Due to Animal Grouping and Handling}

How humans interact with animals can lead to animal welfare problems [79]. This is a subject for the training of staff. All those who handle animals should receive training. The way in which animals are distributed in limited and enclosed areas should be appropriate for their needs. Almost all farm animals are highly gregarious [80], and in the wild, they move in groups of defined numbers within a territorial or home range space [81]. The grouping of animals by human, on many occasions without taking account of their biology or former group composition, can lead to the expression of agonistic behaviors and serious welfare problems due to injuries and stress. The biology of the species must be taken into account, to make an adequate grouping, considering: the number of animals per group, sex, and physiological status [82]. An adequate density should allow freedom of movement of the animals and easy changes of posture. There should be space, at any given time, for all animals to lie down simultaneously with sufficient space between them for thermoregulation and movement. The group size should allow the recognition of all individuals and stable social cohesion [83].

The movement of animals from one place to another should be done in such a way that it does not generate stress or injuries in animals [84]. Driving methods should avoid direct contact, including blows, use of sticks, ropes, electric goads, or sharp objects. It should also be done in a quiet environment and at a steady pace, without causing fear to the animals. There should be avoidance of shouting and high-pitched sounds, since scared animals have a higher risk of slipping, falling, and injury $[85,86]$. Tools to facilitate driving without generating pain or stress in animals include flags and boards. The design and structure of buildings and races play an essential role in allowing easy movement of animals and ensuring good welfare. Poorly designed and poorly managed buildings lead to many welfare problems [85]. The training of stockpeople has been shown to substantially improve animal handling on farms, because it helps them understand the behavior of farm animals, positively modifies their attitudes, and improves their conduct toward animals [87-89]. 
A poor method for capturing animals can cause the animal to collide with hard structures and become injured [88]. Once captured, the animal can be immobilized, if necessary. This immobilization requires adequate equipment, specialized races and other structures, established protocols, and experienced handling by the person handling the animal [89]. Poor quality capture and immobilization generates risks for both the animal and the person who is handling it.

\section{Pain Management}

In animal production systems, many procedures generate pain in animals (see Table 1); both acute and chronic pain have negative consequences for animal welfare [90]. Pain is possibly one of the consequences with the most negative perception for the general public, so improvement in pain management is essential for the animal production industry. Pain can be managed basically in three ways: abolishing painful practice, using anesthesia, and using analgesia. Some practices, such as tail-docking may be abolished because there is no evidence that they generate a benefit for production in good conditions, for quality of milk, or for animal health. The question to consider is whether or not the practice executed is essential and justifiable from various points of view, including animal welfare [59]. Another example is surgical castration, which has been demonstrated to be painful by much research [91-93]. When partial strategies to reduce the pain caused by surgical castration are used, just analgesia or just anesthesia, pain is not completely prevented [94,95]. The pain induced during castration, and during wound healing, leads to activation of adrenal and sympathetic axes [96]. It is well known that adrenal hormones affect immune function, reducing NK cell activity, lymphocyte population, lymphocyte proliferation, antibody production, and reactivation of latent viral infections [97]. These effects have severe consequences for health, including delayed wound healing and impaired responses to vaccination [96]. When a painful practice generates a high level of pain, local or general anesthesia should be used. When a procedure generates pain that is known to remain for a substantial time after the end of the intervention, it is necessary to use analgesia in addition to anesthesia. This pain alleviation is important because some practices in farm animals are legally accepted, for either tradition, cost, convenience, veterinary treatment, sport, or breeding reasons [62].

\section{The Main Welfare Challenges in Production Systems}

Where stress means an environmental effect on an individual which over taxes its control systems and results in adverse consequences and eventually reduced fitness [96], some welfare problems are associated with stress. Some involve pain, some are long-term, and others are short-term. Table 1 is a summary of the most common welfare problems in farm animals. In addition to these problems for the animals, there can be difficulties for care staff if they receive different messages about animal care from owners, veterinarians, and colleagues.

The "one welfare" concept makes it clear that human welfare and non-human animal welfare mean the same thing, and that poor welfare often leads to poor health and other poor welfare, sometimes because the poor welfare suppresses immune system function. Poor welfare that makes production systems more inefficient is likely to have negative effects on human welfare too. Both stress and pain require energy for compensation, so part of the energy consumed by the animal is used to try to deal with welfare problems. The additional energy expenditure resulting from poor welfare reduces productive efficiency and has consequences for the sustainability of the system.

There is already scientific information about many of the causes of poor welfare and practical information about how to improve welfare, yet preventable mistakes that lead to many economic losses are made [98]. Some welfare problems mentioned in Table 1 require that genetic selection of farm animals be modified to reduce productivity since the animals are metabolically over-taxed. There is a trade-off here between what is best for welfare and the desirability of use of efficient production systems so that environmental impact is reduced $[42,47]$. 
Table 1. Widespread welfare issues in domestic animals with usual causes and possible solutions.

\begin{tabular}{|c|c|c|c|c|c|}
\hline Species & Welfare Consequences & From Genetic Selection and Resources & From Animal Handling & Solutions & References \\
\hline \multirow{8}{*}{ Dairy cattle } & Mastitis & $\begin{array}{l}\text { Metabolic pressure from high milk yield } \\
\text { Dirty infrastructure }\end{array}$ & Bad milking practices & $\begin{array}{l}\text { Select and feed for lower yield } \\
\text { Prevention with cleaning and disinfection } \\
\text { Application of good milking practices }\end{array}$ & {$[99,100]$} \\
\hline & Lameness & $\begin{array}{l}\text { Metabolic pressure from high milk yield } \\
\text { Floor quality (hardness, wet, dirt) } \\
\text { Food }\end{array}$ & Absence of podiatry & $\begin{array}{l}\text { Select and feed for lower yield } \\
\text { Improve floor condition } \\
\text { Preventive podiatry } \\
\text { Nutritional management }\end{array}$ & [101] \\
\hline & $\begin{array}{l}\text { Metritis and other reproductive } \\
\text { disorders }\end{array}$ & $\begin{array}{l}\text { Metabolic pressure from high milk yield } \\
\text { Dirty and wet floor } \\
\text { Food inadequacy }\end{array}$ & Bad peripartum protocols & $\begin{array}{c}\text { Select and feed for lower yield } \\
\text { Cleaning and disinfection of surfaces } \\
\text { Protocols of good management peripartum } \\
\text { Nutritional management }\end{array}$ & [102] \\
\hline & Heat stress & $\begin{array}{c}\text { Absence of overheating prevention } \\
\text { mechanisms } \\
\text { Absence of heat dissipation mechanisms } \\
\text { Food }\end{array}$ & $\begin{array}{l}\text { High density } \\
\text { Poor selection of breeds to put on site }\end{array}$ & $\begin{array}{c}\text { Shade } \\
\text { Fans } \\
\text { Water sprinklers } \\
\text { Reduce density } \\
\text { Use adapted breeds }\end{array}$ & [103] \\
\hline & Diarrhoea & $\begin{array}{l}\text { Dirty water } \\
\text { Mishandling of colostrum }\end{array}$ & Bad practices of grouping animals & $\begin{array}{l}\text { Good calf management practices } \\
\text { Improve water quality } \\
\text { Good colostrum management }\end{array}$ & {$[104,105]$} \\
\hline & Respiratory diseases & $\begin{array}{l}\text { Dusty buildings } \\
\text { Cold } \\
\text { High humidity }\end{array}$ & Bad practices of grouping animals & $\begin{array}{l}\text { Dry, clean and larger building } \\
\text { Cold protection } \\
\text { Vaccination }\end{array}$ & [106] \\
\hline & Pain from surgical interventions & Absence of analgesia, anaesthesia & $\begin{array}{c}\text { Dehorning disbudding } \\
\text { Tail docking } \\
\text { Bad restraining practices } \\
\end{array}$ & $\begin{array}{l}\text { Abolish unnecessary procedures } \\
\text { Use anaesthesia and analgesia } \\
\text { Improve restrained protocols }\end{array}$ & [107] \\
\hline & $\begin{array}{c}\text { Social stress and abnormal } \\
\text { behaviours (fights, stereotypies etc.) }\end{array}$ & $\begin{array}{l}\text { Insufficient space and needs not met } \\
\text { Scarce or inaccessible resources for all } \\
\text { animals (includes area, food, water, } \\
\text { enrichments) }\end{array}$ & $\begin{array}{l}\text { Bad practices of grouping, } \\
\text { regrouping and density management }\end{array}$ & $\begin{array}{l}\text { Avoid individual housing in small pens. Good } \\
\text { grouping practices } \\
\text { Ensure that resources are available for all animals }\end{array}$ & [58] \\
\hline
\end{tabular}


Table 1. Cont.

\begin{tabular}{|c|c|c|c|c|c|}
\hline Species & Welfare Consequences & From Genetic Selection and Resources & From Animal Handling & Solutions & References \\
\hline \multirow{5}{*}{ Beef cattle } & $\begin{array}{l}\text { Lameness Swollen joints } \\
\text { Arthritis }\end{array}$ & $\begin{array}{l}\text { Genetic selection for fast growth } \\
\text { Floor quality (Hardness, wet, dirt) }\end{array}$ & $\begin{array}{l}\text { Absence of podiatry } \\
\text { Poor herd handling }\end{array}$ & $\begin{array}{l}\text { Avoid fastest growing strains } \\
\text { Improve floor condition } \\
\text { Preventive podiatry } \\
\text { Nutritional management } \\
\text { Improve management protocols }\end{array}$ & [108-110] \\
\hline & Heat stress & $\begin{array}{l}\text { Absence of overheating prevention } \\
\text { mechanisms } \\
\text { Absence of heat dissipation mechanisms } \\
\text { Inappropriate food }\end{array}$ & $\begin{array}{l}\text { Absence of shadow } \\
\text { Very heavy animals } \\
\text { Breeds with dark hair }\end{array}$ & $\begin{array}{l}\text { Provide shade } \\
\text { Fans } \\
\text { Water sprinklers } \\
\text { Reduce density } \\
\text { Adapted breeds }\end{array}$ & {$[75,111,112]$} \\
\hline & Underfeeding & Poor supply of forage in extensive systems & Poor herd handling & $\begin{array}{l}\text { Improve grazing system } \\
\text { Silvopastoral systems }\end{array}$ & [113] \\
\hline & Pain from surgical interventions & Absence of analgesia, anaesthesia & $\begin{array}{c}\text { Dehorning Disbudding } \\
\text { Bad restrained practices Castration } \\
\text { Hot-iron branding }\end{array}$ & $\begin{array}{l}\text { Abolish unnecessary procedures } \\
\text { Use anaesthesia and analgesia } \\
\text { Improve restraining protocols }\end{array}$ & {$[107,114,115]$} \\
\hline & $\begin{array}{l}\text { Social stress and abnormal } \\
\text { behaviours (fights) }\end{array}$ & $\begin{array}{l}\text { Scarce or inaccessible resources for all animals } \\
\text { (includes area, food, water, enrichments) }\end{array}$ & $\begin{array}{l}\text { Bad practices of grouping, } \\
\text { regrouping and density management }\end{array}$ & $\begin{array}{l}\text { Good grouping practices } \\
\text { Ensure that resources are available for all animals }\end{array}$ & [83] \\
\hline \multirow{7}{*}{ Pigs } & Neonatal mortality & Infrastructure & Bad peripartum practices & $\begin{array}{l}\text { Reduce sow stress before and during parturition } \\
\text { Improve facilities }\end{array}$ & {$[116,117]$} \\
\hline & Weaning & Food change & $\begin{array}{l}\text { Abrupt separation from the mother } \\
\text { at an early age } \\
\text { Mix of unknown groups }\end{array}$ & $\begin{array}{l}\text { Make groups with established hierarchy from } \\
\text { the beginning } \\
\text { Do not mix groups } \\
\text { Leave the animals more days with the mother }\end{array}$ & [118] \\
\hline & $\begin{array}{l}\text { Social stress and abnormal } \\
\text { behaviours (bites, redirected } \\
\text { behaviour and stereotypes) }\end{array}$ & $\begin{array}{c}\text { Individual confinement } \\
\text { Scarce or inaccessible resources for all } \\
\text { animals (includes area, food, water, } \\
\text { environmental enrichments) }\end{array}$ & $\begin{array}{l}\text { Bad practices of grouping, } \\
\text { regrouping and density management }\end{array}$ & $\begin{array}{l}\text { Do not confine in stall or tether } \\
\quad \text { Good grouping practices } \\
\text { Ensure that resources are available for all animals }\end{array}$ & {$[58,119]$} \\
\hline & Heat stress & $\begin{array}{l}\text { Absence of overheating prevention } \\
\text { mechanisms } \\
\text { Absence of heat dissipation mechanisms } \\
\text { Food }\end{array}$ & $\begin{array}{l}\text { High density } \\
\text { Poor selection of breeds to put on site }\end{array}$ & $\begin{array}{c}\text { Fans } \\
\text { Water sprinklers } \\
\text { Reduce density } \\
\text { Adapted breeds }\end{array}$ & [120] \\
\hline & Bursitis & $\begin{array}{l}\text { Inappropriate genetic selection } \\
\text { Infrastructure }\end{array}$ & Bad grouping practices & $\begin{array}{l}\text { Genetic selection to minimise } \\
\text { Infrastructure improvement }\end{array}$ & [121] \\
\hline & Lameness & $\begin{array}{l}\text { Floor quality (hardness, wet, dirt) } \\
\text { Pen conditions } \\
\text { Space restriction } \\
\end{array}$ & Lack of preventive actions & $\begin{array}{l}\text { Improve floor condition } \\
\text { Preventive podiatry }\end{array}$ & [122] \\
\hline & Pain from surgical interventions & Absence of analgesia, anaesthesia & $\begin{array}{l}\text { Tail-docking } \\
\text { Teeth resection } \\
\text { Castration } \\
\text { Ear-tagging } \\
\text { Notching } \\
\text { Bad restrained practices }\end{array}$ & $\begin{array}{l}\text { Abolish unnecessary procedures } \\
\text { Use anaesthesia and analgesia } \\
\text { Improve restrained protocols } \\
\text { Use immunocastration }\end{array}$ & {$[95,96,123]$} \\
\hline
\end{tabular}


Table 1. Cont.

\begin{tabular}{|c|c|c|c|c|c|}
\hline Species & Welfare Consequences & From Genetic Selection and Resources & From Animal Handling & Solutions & References \\
\hline \multirow{4}{*}{$\begin{array}{c}\text { Laying } \\
\text { hens }\end{array}$} & $\begin{array}{l}\text { Foot problems (dermatitis, bumble } \\
\text { foot, hyperketosis, excessive claw } \\
\text { growth) }\end{array}$ & $\begin{array}{l}\text { Floor and facilities quality (hardness, wet, } \\
\text { dirt) }\end{array}$ & Lack of preventive actions & $\begin{array}{c}\text { Litter hygiene } \\
\text { Use low pressure-loading perches } \\
\text { Provide scratching surfaces } \\
\text { Food } \\
\text { Choose healthy breed }\end{array}$ & [124] \\
\hline & $\begin{array}{l}\text { Injurious behaviour (aggression } \\
\text { feather pecking) }\end{array}$ & $\begin{array}{l}\text { Scarce or not accessible resources for all } \\
\text { animals (includes area, food, water, } \\
\text { enrichment, perch to rest) }\end{array}$ & $\begin{array}{l}\text { Housing } \\
\text { density }\end{array}$ & $\begin{array}{l}\text { Avoid conventional cages. } \\
\text { Stable groups } \\
\text { Ensure that resources are sufficient and available for all } \\
\text { animals }\end{array}$ & [125-127] \\
\hline & $\begin{array}{l}\text { Osteoporosis (due to selection for } \\
\text { high egg yield), keel bone fractures }\end{array}$ & $\begin{array}{l}\text { Insufficient space for exercise. } \\
\text { Inadequate diet }\end{array}$ & No evidence from animal handling & $\begin{array}{l}\text { Provide space to exercise and meet all needs. Perch } \\
\text { height/design } \\
\text { Low pressure-loading perches } \\
\text { Provide trajectory clear of objects for movement between } \\
\text { perch \& ground } \\
\text { Breed for bone strength }\end{array}$ & {$[128,129]$} \\
\hline & Mutilations & Absence of analgesia, anaesthesia & $\begin{array}{l}\text { Beak-trimming } \\
\text { Toe-clipping } \\
\text { Dubbing } \\
\text { De-spurring } \\
\end{array}$ & $\begin{array}{l}\text { Abolish unnecessary procedures. } \\
\text { Use anaesthesia and analgesia }\end{array}$ & [125] \\
\hline \multirow{2}{*}{$\begin{array}{l}\text { Meat } \\
\text { poultry }\end{array}$} & $\begin{array}{l}\text { Locomotion problems (poor walking } \\
\text { ability, lameness) } \\
\text { Dermatitis }\end{array}$ & $\begin{array}{l}\text { Growth too fast for leg strength. } \\
\text { Floor and facilities quality (hardness, wet, } \\
\text { dirt) }\end{array}$ & $\begin{array}{l}\text { Lack of preventive actions, e.g., feed } \\
\text { less if growth too fast }\end{array}$ & $\begin{array}{l}\text { Genetic selection for slower growth } \\
\text { Reduce feed } \\
\text { Improve litter hygiene }\end{array}$ & {$[130,131]$} \\
\hline & Heat stress & $\begin{array}{c}\text { Absence of overheating prevention } \\
\text { mechanisms } \\
\text { Absence of heat dissipation mechanisms } \\
\text { Food }\end{array}$ & $\begin{array}{l}\text { High density. } \\
\text { Poor selection of breeds to put on site }\end{array}$ & $\begin{array}{l}\text { Fans } \\
\text { Reduce density } \\
\text { Adapted breeds }\end{array}$ & [133] \\
\hline \multirow{5}{*}{ Fish } & Physiological disorders & Poor water quality & Stocking density too high & $\begin{array}{c}\text { Ensure good aeration and water quality } \\
\text { Appropriate and sufficient space } \\
\text { Reduce stocking density } \\
\end{array}$ & {$[134,135]$} \\
\hline & Fin erosion & Infrastructure (floating cages, ponds) & Stocking density too high & $\begin{array}{l}\text { Infrastructure preventive maintenance } \\
\text { Reduce stocking density }\end{array}$ & [136] \\
\hline & Hunger & Insufficient food & $\begin{array}{c}\text { Fasting } \\
\text { Poor food distribution }\end{array}$ & $\begin{array}{c}\text { Reduce stocking density } \\
\text { Improve food distribution so all fish get sufficient food }\end{array}$ & {$[137,138]$} \\
\hline & Exposure to air & Insufficient space & Poor handling procedures & Avoid air exposure & [139] \\
\hline & Aggression & $\begin{array}{l}\text { Lack of resources } \\
\text { Insufficient space }\end{array}$ & Stocking density too high & $\begin{array}{l}\text { Reduce stocking density } \\
\text { Good grouping practices } \\
\text { Ensure that resources are available for all animals }\end{array}$ & [137] \\
\hline
\end{tabular}


Table 1. Cont.

\begin{tabular}{|c|c|c|c|c|c|}
\hline Species & Welfare Consequences & From Genetic Selection and Resources & From Animal Handling & Solutions & References \\
\hline \multirow{7}{*}{ Horses } & Aversive Taming & Inadequate taming space & Soring and abusive training methods & Good taming and training practices & [140] \\
\hline & $\begin{array}{l}\text { Overload and overexertion } \\
\text { (Carriage and by stockpeople) }\end{array}$ & Inappropriate saddles and bridles & Poor handling procedures & $\begin{array}{l}\text { Appropriate calculation of load capacity } \\
\text { Adequate design and use of saddles and bridles } \\
\text { Improve handling procedures } \\
\text { Appropriate workload timing }\end{array}$ & [140-142] \\
\hline & $\begin{array}{l}\text { Discomfort from uncomfortable } \\
\text { saddles and bridles }\end{array}$ & Inappropriate saddles and bridles & Poor handling procedures & $\begin{array}{l}\text { Adequate design and use of saddles and bridles } \\
\text { Improve handling procedures }\end{array}$ & [143] \\
\hline & Colic & Multifactorial & Poor handling procedures & $\begin{array}{c}\text { Ensure water quality and availability } \\
\text { Allow pasture access } \\
\text { Avoid feeding hay on the ground in sandy areas } \\
\text { Feed grain and pelleted feeds only when necessary } \\
\text { Allow exercise } \\
\text { Control parasites } \\
\text { Ensure dental care }\end{array}$ & [144] \\
\hline & $\begin{array}{l}\text { Abnormal behaviour (including } \\
\text { stereotypies) }\end{array}$ & $\begin{array}{l}\text { Individual housing. Density. } \\
\text { Absence of enrichments }\end{array}$ & $\begin{array}{l}\text { Social isolation. Poor human-animal } \\
\text { relationship }\end{array}$ & $\begin{array}{l}\text { Avoid individual housing } \\
\text { Allow socialisation } \\
\text { Environmental enrichment } \\
\text { Training }\end{array}$ & {$[58,145]$} \\
\hline & Locomotion problems (lameness) & $\begin{array}{c}\text { Floor and facility quality (Hardness, wet, dirt) } \\
\text { Inadequate feeding } \\
\text { Injurie }\end{array}$ & Lack of preventive actions & $\begin{array}{l}\text { Improve floor condition } \\
\text { Preventive podiatry }\end{array}$ & {$[141,145,146]$} \\
\hline & $\begin{array}{l}\text { Hunger and dehydration (working } \\
\text { horses) }\end{array}$ & $\begin{array}{l}\text { Absence of sufficient water. } \\
\text { Absence of sufficient food }\end{array}$ & Bad practices in food handling & $\begin{array}{l}\text { Adequate supply of food and water in quality, quantity, } \\
\text { and availability }\end{array}$ & {$[141,142,145]$} \\
\hline \multirow{7}{*}{ Dogs } & Hunger and dehydration (stray dog) & $\begin{array}{l}\text { Absence of sufficient water. } \\
\text { Absence of sufficient food }\end{array}$ & $\begin{array}{l}\text { Abandonment of animals } \\
\text { Animals without owner }\end{array}$ & $\begin{array}{l}\text { Control programs for stray animals } \\
\text { Feeding in shelter } \\
\text { Provide water and food supply }\end{array}$ & [147] \\
\hline & Breed related conditions & $\begin{array}{l}\text { Genetic selection for flat faces and other } \\
\text { characters }\end{array}$ & $\begin{array}{l}\text { Individuals allow breeding of dogs } \\
\text { with genetic abnormalities }\end{array}$ & $\begin{array}{l}\text { Avoid selection pressure for unadaptive "aesthetic" qualities } \\
\text { Increase genetic diversity } \\
\text { Do not allow dogs with flat faces to breed }\end{array}$ & [148] \\
\hline & Obesity (pet dogs) & Overfeeding & Lack of exercise & $\begin{array}{l}\text { Proper management of balanced diets } \\
\text { Regular exercise }\end{array}$ & [149] \\
\hline & Chronic pain (stray and pet dogs) & Failure to provide analgesia & $\begin{array}{l}\text { Failure to use analgesia. Absence of } \\
\text { veterinary treatment }\end{array}$ & $\begin{array}{l}\text { Preventive veterinary medicine and timely pain treatment } \\
\text { Use analgesia }\end{array}$ & [150] \\
\hline & Behavioural problems (pet dogs) & $\begin{array}{l}\text { Absence of enrichment } \\
\text { Space }\end{array}$ & $\begin{array}{l}\text { Absence of early education } \\
\text { Inappropriate grouping } \\
\text { Social isolation } \\
\text { Poor human-animal relationship }\end{array}$ & $\begin{array}{c}\text { Owner education } \\
\text { Animal training } \\
\text { Appropriate stimuli, do not leave dogs without other } \\
\text { dogs or people for long periods } \\
\text { Exercise } \\
\text { Socialization }\end{array}$ & [151] \\
\hline & Injuries (dog fighting) & Insufficient space & Inadequate grouping & Abolition of dogfights & [152] \\
\hline & Mutilations & $\begin{array}{l}\text { Absence of use of anaesthesia and/or } \\
\text { analgesia }\end{array}$ & Ear cropping and tail docking & Abolish unnecessary procedures & [153] \\
\hline
\end{tabular}




\section{Animal Production Systems, Human Health, and Environmental Impact}

Under the concept of "one health", it is understood that the health of humans and other animals are the same concept and area of effect [154]; therefore, the maintenance of health in production systems has positive repercussions on the assurance of good human health and mean health in all populations. The concept of One Welfare arises as a complement to the one health approach $[154,155]$; The fields of human and non-human welfare are empowered by addressing more effectively the connection between policy and science, including environmental science and sustainability. There is interconnection between the environment and the welfare of all animals, including humans [156]. Since the most prolonged and important human interaction with other animals is with pets and indirectly with the products of farm animals, Table 2 shows the main zoonotic diseases, excluding many that are transmitted by wild animals.

Table 2. Most significant zoonotic diseases around the world. Listed by alphabetic order, not importance order. Adapted from the OIE-Listed diseases 2019.

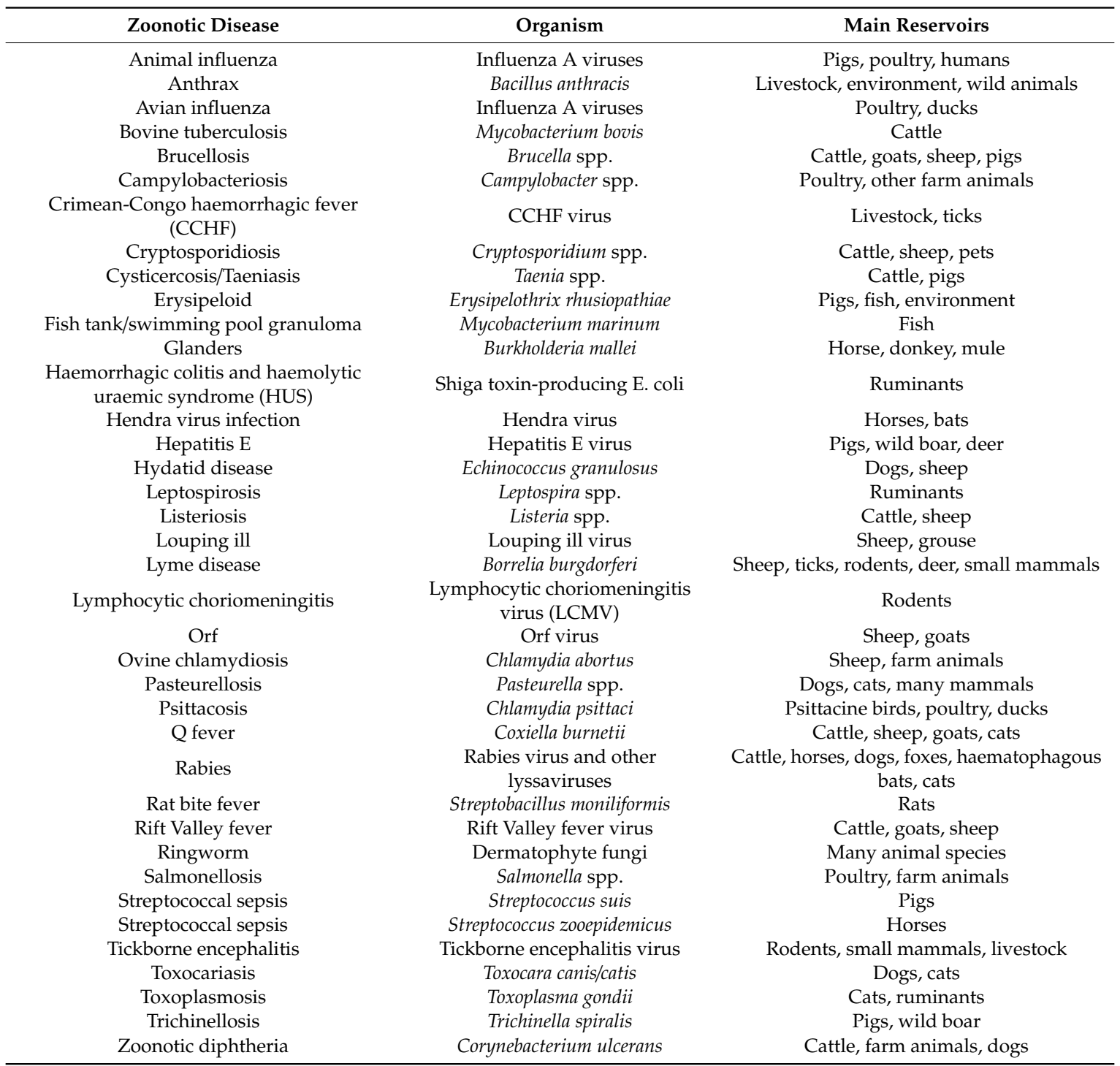

\section{Consequences of Human-Animal Relations for The Environment}

In addition to the human-animal interaction problem of humans getting diseases directly from non-human animals, a further major problem is that human actions are having adverse effects on ecosystems and the whole world environment. This paradigm is not new; it began last century with 
the issue of climate change and global warming, which triggered alarms, especially for considering animal production systems as significantly responsible for greenhouse gas production and having a very large water and carbon footprint [157]. The need for a focus of attention on the impact of animal production on the environment has been strongly emphasized [158]. Livestock are described as one of the biggest factors responsible for climate change. Whilst there is now evidence that refutes several of these claims [159], the publication generated such a degree of discomfort with its assertions that it encouraged scientific investigation of the subject and efforts to refute the conclusions [159-162]. One of the issues is that data often refer to only one system and this can be misleading. For example, whilst [158] and many other publications use largely beef feedlot system data when referring to beef impacts, beef production from feedlot systems is much worse for conserved water usage than extensive pasture, fertilized pasture, and semi-intensive silvopastoral systems; the last is a form of agroforestry, typically integrating three-level plant production, including improved pastures, high densities fodder shrubs with edible leaves, and timber, fruit or palm trees, that may also have edible leaves [163]. Land use is highest for extensive pasture and higher for feedlot systems than that for semi-intensive silvopastoral systems [47]. Another important issue is that herbivorous animals such as cattle, sheep and some farmed fish can consume material that humans cannot consume. If the food products of these herbivorous animals are consumed, world resources are used more efficiently if they are not fed grain or other potential human food. It can be considered wasteful for human food to be fed to animals with a big loss of food availability to humans [163,164]. Broom [165] states that any effect which the general public find unacceptable makes a system unsustainable, for example: inefficient use of world resources, adverse effects on human health, negative impacts on animal welfare, harmful environmental effects, unacceptable genetic modification, not being "fair trade" or damage to rural communities. Some alternative solutions are agroforestry and the use of silvopastoral systems [166,167]. It has been shown that applying the principles of animal welfare for health assurance and maintenance of productive efficiency also has a direct impact on sustainability [163] and that some systems with high animal welfare standards are good for most other aspects of sustainability [168].

As an example of this are the set of "sustainable development goals (SDGs)" that the United Nations adopted in 2015, to reach 2030, a scenario without hunger and poverty, safe from the critical effects of climate change and loss of biodiversity [169]. A workshop called "Animal Welfare and the Sustainable Development Goals" in 2018 at the Swedish University of Agricultural Science had a group of 12 active participants, from eight countries, with an academic background in agricultural or veterinary science. They evaluated every goal and found that although animal welfare was not explicitly mentioned in the SDGs, working to achieve those goals is compatible with working the improvement of animal welfare [170].

\section{Conclusions}

Consideration of the welfare, including the health, of humans and consideration of welfare and disease spread in other animals, cannot be separated from evaluating the consequences of human decisions about the natural world. We ought to try to take account of each living being, and each community, population, and ecosystem; otherwise, human as well as other life could be endangered. Proposals are made to take account of the concepts of one health, one welfare, one biology; and to apply them to daily decisions about production systems. Animal welfare is fundamental to making decisions about the global consequences of our relationships with domestic animals, not only the direct impact of manipulating them, but also the effect on the environment, on disease spread, natural resource availability, culture, and society. A series of possible solutions are presented for a wide range of animal welfare problems, taking account, where relevant, of zoonotic and other diseases.

Author Contributions: Conceptualization, A.M.T., M.C.C. and D.M.B.; methodology, A.M.T., M.C.C. and D.M.B.; investigation, A.M.T., M.C.C. and D.M.B.; writing—original draft preparation, A.M.T. and M.C.C.; writing-review and editing, A.M.T., M.C.C. and D.M.B.; funding acquisition, A.M.T. All authors have read and agreed to the published version of the manuscript. 
Funding: This research was funded by grant 1115574558712, Project: Sistemas agropecuarios resilientes en el trópico húmedo para la ruralidad del posconflicto. Convocatoria 745- COLCIENCIAS.

Acknowledgments: We express our gratitude to COLCIENCIAS for the financial support. We thank Ximena Tarazona and Adelina Velez for their help in formatting the manuscript.

Conflicts of Interest: The authors declare no conflict of interest.

\section{References}

1. Vaughan, T.A.; Ryan, J.M.; Czaplewski, N.J. Mammalogy, 6th ed.; Jones \& Bartlett: Burlington, MA, USA, 2015.

2. Premack, D. Human and animal cognition: Continuity and discontinuity. Proc. Natl. Acad. Sci. USA 2007, 104, 13861-13867. [CrossRef]

3. Broom, D.M. The Evolution of Morality and Religion; Cambridge University Press: Cambridge, UK, 2003.

4. Broom, D.M. Sentience and Animal Welfar; CABI Publishing: Wallingford, UK, 2014.

5. McBride, S.D.; Morton, A.J. Indices of comparative cognition: Assessing animal models of human brain function. Exp. Brain Res. 2018, 236, 3379-3390. [CrossRef] [PubMed]

6. Falk, D.; Hofman, M.A. Evolution of the Primate Brain from Neuron to Behavior, 1st ed.; Elsevier: Amsterdam, The Netherlands, 2012; p. 195. ISBN 978-0-444-53860-4.

7. Webb, C.E.; Romero, T.; Franks, B.; Waal, F. Long-term consistency in chimpanzee consolation behaviour reflects empathetic personalities. Nat. Commun. 2017, 8, 292. [CrossRef] [PubMed]

8. Custance, D.; Mayer, J. Empathic-like responding by domestic dogs (Canis familiaris) to distress in humans: An exploratory study. Anim. Cogn. 2012, 15, 851-859. [CrossRef] [PubMed]

9. Pérez, A.; Gomila, A. The comparative study of empathy: Sympathetic concern and empathic perspective-taking in non-human animals. Biol. Rev. 2018, 93, 248-269. [CrossRef]

10. de Waal, F.B.M. Are We Smart Enough to Know How Smart Animals Are? W.W. Norton \& Company: New York, NY, USA, 2016; ISBN 978-0-393-35366-2.

11. Broom, D.M. The biological basis for religion and religion's evolutionary origins. In The Evolution of Religion, Religiosity and Theology: A Multi-Level and Multi-Disciplinary Approach; Feierman, J., Oviedo, L., Eds.; Routledge: London, UK, 2019; pp. 70-83. ISBN 9780429285608.

12. Skinner, M. Encyclopedia of Reproduction, 2nd ed.; Academic Press: San Diego, CA, USA, 2018; ISBN 9780128118993.

13. Cooper, T.G.; Noonan, E.; von Eckardstein, S.; Auger, J.; Baker, G.; Behre, H.M.; Haugen, T.B.; Kruger, T.; Wang, C.; Michael, T.; et al. World Health Organization reference values for human semen characteristics. Hum. Reprod. Update 2010, 16, 231-245. [CrossRef]

14. Zhou, J.; Wang, B.; Hu, Y.; Sun, H. Association between the number of oocytes retrieved and cumulative live birth rate in women aged 35-40 years undergoing long GnRH agonist IVF/ICSI cycles. Arch. Gynecol. Obstet. 2017, 296, 1005-1012. [CrossRef]

15. Gabora, L.; Russon, A. The evolution of human intelligence. In The Cambridge Handbook of Intelligence; Sternberg, R., Kaufman, S., Eds.; Cambridge University Press: Cambridge, UK, 2011; pp. 328-350. [CrossRef]

16. IFR. A positioning paper by the International Federation of Robotics. In The Impact of Robots on Productivity, Employment and Jobs; International Federation of Robotics: Frankfurt, Germany, 2018; Available online: https://ifr.org/downloads/papers/IFR_The_Impact_of_Robots_on_Employment_Positioning_Paper_ updated_version_2018.pdf (accessed on 27 October 2019).

17. Hofman, M.A. Evolution of the human brain: When bigger is better. Front. Neuroanat. 2014, 8, 15. [CrossRef]

18. Broom, D.M. Welfare, stress and the evolution of feelings. Adv. Study Behav. 1998, 27, 371-403. [CrossRef]

19. Boffelli, D.; Nobrega, M.A.; Rubin, E.M. Comparative genomics at the vertebrate extremes. Nat. Rev. Genet. 2004, 5, 456-465. [CrossRef]

20. Broom, D.M. Indicators of poor welfare. Br. Vet. J. 1986, 142, 524-526. [CrossRef]

21. Broom, D.M. Behaviour and welfare in relation to pathology. Appl. Anim. Behav. Sci. 2006, 97, 71-83. [CrossRef]

22. Kolber, E. La Sexta Extinción: Una Historia Nada Natural; Editorial Crítica: Barcelona, Spain, 2014; ISBN 978-849-89-2779-5.

23. Armitage, S.J.; Jasim, S.A.; Marks, A.E.; Parker, A.G.; Usik, V.I.; Uerpmann, H.P. Hints of earlier human exit from Africa. Science 2011, 331, 453-456. [CrossRef] [PubMed] 
24. Manhesa, G.; Allègre, C.J.; Dupréa, B.; Hamelin, B. Lead isotope study of basic-ultrabasic layered complexes: Speculations about the age of the earth and primitive mantle characteristics. Earth Planet. Sci. Lett. 1980, 47, 370-382. [CrossRef]

25. Gershwin, L. Jellyfish: A Natural History; University of Chicago Press: Chicago, IL, USA, 2016. [CrossRef]

26. Bell, W.J.; Roth, L.M.; Nalepa, C.A. Cockroaches: Ecology, Behavior, and Natural History; The Johns Hopkins University Press: Baltimore, MD, USA, 2007.

27. Vigne, J.D. The origins of animal domestication and husbandry: A major change in the history of humanity and the biosphere. Comptes Rendus Biol. 2011, 334, 171-181. [CrossRef]

28. Zeder, M. Central questions in the domestication of plants and animals. Evol. Anthropol. 2006, 15, $105-117$. [CrossRef]

29. Zeder, M. The Domestication of animals. Rev. Anthropol. 1982, 9, 321-327. [CrossRef]

30. Larson, G.; Fuller, D.Q. The evolution of animal domestication. Annu. Rev. Ecol. Evol. Syst. 2014, 45, 115-136. [CrossRef]

31. Grandgeorge, M.; Hausberger, M. Human-animal relationships: From daily life to animal-assisted therapies. Ann. Dellist. Super. Sanità 2011, 47,397-408. [CrossRef]

32. Shipman, P. The animal connection and human evolution. Curr. Anthropol. 2010, 51, 519-538. [CrossRef]

33. Broom, D. A history of animal welfare science. Acta Biotheor. 2011, 59, 121-137. [CrossRef] [PubMed]

34. Vries, P. The industrial revolution. In Encyclopaedia of the Modern World; Oxford University Press: Oxford, UK, 2008; Volume 4, pp. 158-161. [CrossRef]

35. Bhada-Tata, P.; Hoornweg, D.A. What a Waste?: A Global Review of Solid Waste Management; World Bank Group: Washington, DC, USA, 2012; Available online: http://documents.worldbank.org/curated/en/302341468126264791/ What-a-waste-a-global-review-of-solid-waste-management (accessed on 27 October 2019).

36. Cohen, J.E. Cities and climate change: A review essay. Popul. Dev. Rev. 2019, 45, 425-435. [CrossRef]

37. WHO; FAO; OIE. Report of the WHO/FAO/OIE joint consultation on emerging zoonotic diseases. In Proceedings of the WHO/FAO/OIE Joint Consultation on Emerging Zoonotic Diseases, Geneva, Switzerland, 3-5 May 2004; Available online: https://apps.who.int/iris/bitstream/handle/10665/68899/WHO_CDS_CPE_ ZFK_2004.9.pdf?sequence=1 (accessed on 27 October 2019).

38. Appannagari, R.R. Environmental pollution causes and consequences: A study. North Asian Int. Res. J. Soc. Sci. Humanit. 2017, 3, 151-161.

39. Moutinho, P. Deforestation around the World; InTech: Rijeka, Croatia, 2012; ISBN 978-953-51-0417-9386.

40. Sonter, L.J.; Ali, S.H.; Watson, J. Mining and biodiversity: Key issues and research needs in conservation science. Proc. Biol. Sci. 2018, 285. [CrossRef] [PubMed]

41. Broom, D.M. Animal welfare in the European Union. In Citizen's Rights and Constitutional Affairs; European Parliament Policy Department: Brussels, Belgium, 2017; ISBN 978-92-846-0543-9.

42. Balmford, A.; Amano, T.; Bartlett, H.; Chadwick, D.; Collins, A.; Edwards, D.; Field, R.; Garnsworthy, P.; Green, R.; Smith, P.; et al. The environmental costs and benefits of high-yield farming. Nat. Sustain. 2018, 1, 477-485. [CrossRef] [PubMed]

43. Broom, D.M. Animal welfare: An aspect of care, sustainability, and food quality required by the public. J. Vet. Med. Educ. 2010, 37, 83-88. [CrossRef]

44. Broom, D.M. International animal welfare perspectives, including whaling and inhumane seal killing as a public morality issue. In Animal Law and Welfare-International Perspectives; Cao, D., White, S., Eds.; Springer International Publishing: Cham, Switzerland, 2016; pp. 45-61. [CrossRef]

45. Thornton, P.K. Livestock production: Recent trends, future prospects. Philos. Trans. R. Soc. B. Biol. Sci. 2010, 365, 2853-2867. [CrossRef]

46. Hoekstra, A.Y.; Chapagain, A.K.; Aldaya, M.M.; Mekonnen, M.M. The Water Footprint Assessment Manual: Setting the Global Standard; Earthscan: London, UK; Washington, DC, USA, 2011; p. 203. ISBN 978-1-84971-279-8.

47. Broom, D.M. Land and Water Usage in Beef Production Systems. Animals 2019, 9, 286. [CrossRef]

48. Sicheng, S.; Yongyou, H.; Jianhua, C.; Yuancai, C. Research progress on distribution, migration, transformation of antibiotics and antibiotic resistance genes (ARGs) in aquatic environment. Crit. Rev. Biotechnol. 2018, 38, 1195-1208. [CrossRef]

49. Jordan, T.; Lem, M. One Health, One Welfare: Education in practice veterinary students' experiences with Community Veterinary Outreach. Can. Vet. J. 2014, 55, 1203-1206. 
50. Thumbi, S.M.; Njenga, M.K.; Marsh, T.L.; Noh, S.; Otiang, E.; Munyua, P.; Ochieng, L.; Ogola, E.; Yoder, J.; Audi, A.; et al. Linking human health and livestock health: A "one-health" platform for integrated analysis of human health, livestock health, and economic welfare in livestock dependent communities. PLoS ONE 2015, 10. [CrossRef] [PubMed]

51. Buller, H.; Blokhuis, H.; Jensen, P.; Keeling, L. Towards Farm Animal Welfare and Sustainability. Animals 2018, 8, 81. [CrossRef] [PubMed]

52. Ceballos, M.C.; Sant'Anna, A.C. Evolução da ciência do bem-estar animal: Aspectos conceituais e metodológicos. Rev. Acad. Cienc. Anim. 2018, 16, 1-24. [CrossRef]

53. FAWC. Farm Animal Welfare in Great Britain: Past, Present and Future; Farm Animal Welfare Council: London, UK, 2009. Available online: https://assets.publishing.service.gov.uk/government/uploads/system/uploads/ attachment_data/file/319292/Farm_Animal_Welfare_in_Great_Britain_-_Past_Present_and_Future.pdf (accessed on 27 October 2019).

54. Edgar, J.L.; Mullen, S.M.; Pritchard, J.C.; McFarlane, U.J.C.; Main, D.C.J. Towards a "good life" for farm animals: Development of a resource tier framework to achieve positive welfare for laying hens. Animals 2013, 7, 584-605. [CrossRef] [PubMed]

55. Mellor, D. Updating animal welfare thinking: Moving beyond the "Five Freedoms" towards "a Life Worth Living". Animals 2016, 6, 21. [CrossRef] [PubMed]

56. Broom, D.M. Quality of life means welfare: How is it related to other concepts and assessed? Anim. Welf. 2007, 16, 45-53.

57. Marchant-Forde, J.N. The science of animal behavior and welfare: Challenges, opportunities, and global perspective. Front. Vet. Sci. 2015, 2, 16. [CrossRef]

58. Broom, D.M.; Fraser, A.F. Domestic Animal Behaviour and Welfare, 5th ed.; CABI: Wallingford, CT, USA, 2015; p. 472. [CrossRef]

59. Mendl, M.; Burman, O.H.P.; Paul, E.S. An integrative and functional framework for the study of animal emotion and mood. Proc. R. Soc. B 2010, 277, 2895-2904. [CrossRef]

60. Mellor, D.J.; Beausoleil, N.J. Extending the 'Five Domains' model for animal welfare assessment to incorporate positive welfare states. Anim. Welf. 2015, 24, 241-253. [CrossRef]

61. Broom, D.M. Animal welfare: Concepts and measurement. J. Anim. Sci. 1991, 69, 4167-4175. [CrossRef]

62. Broom, D. Legally accepted pain and other poor welfare in animals. In Animal Welfare: From Science to Law; Hild, S., Schweitzer, L., Eds.; L'Harmattan: Paris, France, 2019; ISBN 978-2-9512167-4-7.

63. de Passillé, A.M.; Rushen, J. Food safety and environmental issues in animal welfare. Rev. Sci. Tech. Off. Int. Epiz. 2005, 24, 757-766. [CrossRef]

64. Ouweltjes, W.; Spoor, C.W.; van Leeuwen, J.L.; Gussekloo, S.W.S. Spatial distribution of load induced soft-tissue strain in cattle claws. Vet. J. 2019, 248, 28-36. [CrossRef] [PubMed]

65. Devillers, N.; Janvier, E.; Delijani, F.; Méthot, S.; Dick, K.J.; Zhang, Q.; Connor, L. Effect of Slat and Gap Width of Slatted Concrete Flooring on Sow Gait Using Kinematics Analysis. Animals 2019, 9, 206. [CrossRef] [PubMed]

66. Weiss, M.; Hainke, K.; Grund, S.; Gerlach, K.; Mülling, C.K.W.; Geiger, S.M. Does the range of motion in the bovine interphalangeal joints change with flooring condition? A pilot study using biplane high-speed fluoroscopic kinematography. J. Dairy Sci. 2019, 102, 1443-1456. [CrossRef]

67. Stella, J.; Hurt, M.; Bauer, A.; Gomes, P.; Ruple, A.; Beck, A.; Croney, C. Does Flooring Substrate Impact Kennel and Dog Cleanliness in Commercial Breeding Facilities? Animals 2018, 8, 59. [CrossRef]

68. Grandin, T. On-farm conditions that compromise animal welfare that can be monitored at the slaughter plant. Meat Sci. 2017, 132, 52-58. [CrossRef]

69. Almeida, E.A.; de Souza, F.A.; Furlan, R.L.; Turco, J.E.; Milani, A.P. Thermal behavior of metallic and fiber cement tiles with simple and double layers. J. Anim. Behav. Biometeorol. 2018, 6, 72-76. [CrossRef]

70. Mikovits, C.; Zollitsch, W.; Hörtenhuber, S.J.; Baumgartner, J.; Niebuhr, K.; Piringer, M.; Anders, I.; Andre, K.; Hennig-Pauka, I.; Schönhar, M.; et al. Impacts of global warming on confined livestock systems for growing-fattening pigs: Simulation of heat stress for 1981 to 2017 in Central Europe. Int. J. Biometeorol. 2019, 63, 221. [CrossRef]

71. Xie, Q.; Ni, J.; Su, Z. Fuzzy comprehensive evaluation of multiple environmental factors for swine building assessment and control. J. Hazard. Mater. 2017, 340, 463-471. [CrossRef] 
72. Sevillano, C.A.; Mulder, H.A.; Rashidi, H.; Mathur, P.K.; Knol, E.F. Genetic variation for farrowing rate in pigs in response to change in photoperiod and ambient temperature. J. Anim. Sci. 2016, 94, 3185-3197. [CrossRef]

73. McCafferty, G.; Pandraud, J.G.; Fabra-Puchol, M.; Henry, P.Y. Animal thermoregulation: A review of insulation, physiology and behaviour relevant to temperature control in buildings. Bioinspir. Biomim. 2017, 13. [CrossRef] [PubMed]

74. Willcox, J.L.; Marks, S.L.; Ueda, Y.; Skorupski, K.A. Clinical features and outcome of dermal squamous cell carcinoma in 193 dogs 1987-2017. Vet. Comp. Oncol. 2019, 17, 130-138. [CrossRef] [PubMed]

75. Grandin, T. Evaluation of the welfare of cattle housed in outdoor feedlot pens. Vet. Anim. Sci. 2016, 1, 23-28. [CrossRef]

76. McClendon, C.J.; Gerald, C.L.; Waterman, J.T. Farm animal models of organic dust exposure and toxicity: Insights and implications for respiratory health. Curr. Opin. Allergy Clin. Immunol. 2015, 5, 137-144. [CrossRef] [PubMed]

77. Maier, G.U.; Love, W.J.; Karle, B.M.; Dubrovsky, S.A.; Williams, D.R.; Champagne, J.D.; Aly, S.S. Management factors associated with bovine respiratory disease in preweaned calves on California dairies: The BRD 100 study. J. Dairy Sci. 2019, 102, 7288-7305. [CrossRef] [PubMed]

78. Newberry, R.C. Environmental enrichment: Increasing the biological relevance of captive environments. Appl. Anim. Behav. Sci. 1995, 44, 229-243. [CrossRef]

79. Grandin, T. Livestock Handling and Transport, 3rd ed.; CABI: Fort Collins, CO, USA, 2007; ISBN 9781845932190.

80. Grandin, T. Transferring results of behavioral research to industry to improve animal welfare on the farm, ranch and the slaughter plant. Appl. Anim. Behav. Sci. 2003, 81, 215-228. [CrossRef]

81. Ceballos, M.C.; Sant'Anna, A.C.; Góis, K.C.R.; Ferraudo, A.S.; Negrao, J.A.; da Costa, M.J.P. Investigating the relationship between human-animal interactions, reactivity, stress response and reproductive performance in Nellore heifers. Livest. Sci. 2018, 217, 65-75. [CrossRef]

82. Forkman, B.; Boissy, A.; Meunier-Salaün, M.C.; Canali, E.; Jones, R.B. A critical review of fear tests used on cattle, pigs, sheep, poultry and horses. Physiol. Behav. 2007, 92, 340-374. [CrossRef]

83. Grandin, T. Welfare Problems in Cattle, Pigs, and Sheep that Persist Even Though Scientific Research Clearly Shows How to Prevent Them. Animals 2018, 8, 124. [CrossRef]

84. De Lima, V.A.; Ceballos, M.C.; Gregory, N.G.; Da Costa, M.J. Effect of different catching practices during manual upright handling on broiler welfare and behavior. Poult. Sci. 2019, 98, 4282-4289. [CrossRef] [PubMed]

85. Brown, H.; Elliston, N.G.; McAskill, J.W.; Tonkinson, L.V. The effect of restraining fat cattle prior to slaughter on the incidence and severity of injuries resulting in carcass bruises. West. Sect. Am. Soc. Anim. Sci. 1981, 33, 363-365.

86. Mota, D.; Ceballos, M.C.; Orihuela, A.; Corredor, M.C.; Perez, E.; Ramirez, R.; Cesar, D. Prácticas dolorosas en animales de granja. In Bienestar Animal: Una Visión Global En Iberoamérica, 3rd ed.; Mota, D., Velarde, A., Huertas, S.M., Cajiao, M.N., Eds.; Elsevier: Barcelona, Spain, 2016; Volume 1, pp. 137-154. ISBN 9788491130260.

87. Soler, M. Adaptative Behavior: Understanding the Human Animal; Síntesis: Madrid, Spain, 2012; ISBN 978-84-695-2471-8.

88. Ceballos, M.C.; Góis, K.C.R. Implicações da relação humano-animal no bem-estar dos animais de fazenda. Rev. Bras. Zoociênc. 2016, 17, 45-50.

89. Ceballos, M.C.; Sant'Anna, A.C.; Boivin, X.; de Oliveira Costa, F.; Monique, V.D.L.; da Costa, M.J.P. Impact of good practices of handling training on beef cattle welfare and stockpeople attitudes and behaviors. Livest. Sci. 2018, 216, 24-31. [CrossRef]

90. Taylor, A.A.; Weary, D.R. Vocal responses of piglets to castration: Identifying procedural sources of pain. Appl. Anim. Behav. Sci. 2000, 70, 17-26. [CrossRef]

91. Hay, M.; Vulin, A.; Génin, S.; Sales, P.; Prunier, A. Assessment of pain induced by castration in piglets: Behavioral and physiological responses over the subsequent 5 days. Appl. Anim. Behav. Sci. 2003, 82, 201-218. [CrossRef]

92. Prunier, A.; Bonneau, M.; von Borell, E.H.; Cinotti, S.; Gunn, M.; Fredriksen, B.; Giersing, M.; Morton, D.B.; Tuyttens, A.M.; Velarde, A. A review of the welfare consequences of surgical castration in piglets and the evaluation of non-surgical methods. Anim. Welf. 2006, 15, 277-289.

93. Rault, J.L.; Lay, D.C. Nitrous oxide by itself is insufficient to relieve pain due to castration in piglets. J. Anim. Sci. 2011, 89, 3318-3325. [CrossRef] 
94. Marchant, J.N.; Lay, D.C.; McMunn, K.A.; Cheng, H.W.; Pajor, E.A.; Marchant, R.M. Postnatal piglet husbandry practices and well-being: The effects of alternative techniques delivered separately. J. Anim. Sci. 2014, 92, 1150-1160. [CrossRef]

95. Yun, J.; Ollila, A.; Valros, A.; Larenza-Menzies, P.; Heinonen, M.; Oliviero, C.; Peltoniemi, O. Behavioural alterations in piglets after surgical castration: Effects of analgesia and anaesthesia. Res. Vet. Sci. 2019, 125, 36-42. [CrossRef]

96. Broom, D.M.; Johnson, K.G. Stress and Animal Welfare; Springer: Berlin/Heidelberg, Germany; Kluwer Scientific \& Business Media: Luxemburg, 1993; ISBN 9789402409802.

97. Webster, J.I.; Glaser, R. Stress hormones and immune function. Cell. Immunol. 2008, 252, 16-26. [CrossRef] [PubMed]

98. Grandin, T. Livestock-handling assessments to improve the welfare of cattle, pigs and sheep. Anim. Prod. Sci. 2018, 58, 403-407. [CrossRef]

99. Schukken, Y.H.; Tikofsky, L.L.; Zadoks, R.N. Environmental control for mastitis prevention, milk quality and food safety. In Mastitis in Dairy Production: Current Knowledge and Future Solutions; Hogeveen, H., Ed.; Wageningen Academic Publishers: Wageningen, The Netherlands, 2005; pp. 109-114.

100. Sant'Anna, A.C.; Paranhos da Costa, M.J.R. The Relationship between Dairy Cow Hygiene and Somatic Cell Count in Milk. J. Dairy Sci. 2011, 94, 3835-3844. [CrossRef] [PubMed]

101. Bran, J.A.; Costa, J.H.; von Keyserlingk, M.A.; Hötzel, M.J. Factors associated with lameness prevalence in lactating cows housed in freestall and compost-bedded pack dairy farms in southern Brazil. Prev. Vet. Med. 2019, 172. [CrossRef]

102. von Keyserlingk, M.A.G.; Rushen, A.M.; de Passillé, D.M. Weary, Invited review: The welfare of dairy cattle-Key concepts and the role of science. J. Dairy Sci. 2009, 92, 4101-4111. [CrossRef]

103. Polsky, L.; von Keyserlingk, M.A.G. Invited review: Effects of heat stress on dairy cattle welfare. J. Dairy Sci. 2017, 100, 8645-8657. [CrossRef]

104. Katsuji, U. Newborn calf welfare: A review focusing on mortality rates. Anim. Sci. J. 2013, 84, 101-105. [CrossRef]

105. Cho, Y.I.; Yoon, K.J. An overview of calf diarrhea-infectious etiology, diagnosis, and intervention. J. Vet. Sci. 2014, 15, 1-17. [CrossRef]

106. Bojkovski, J.; Milanov, D.; Vasic, A.; Zdravković, N.; Rogožarski, D.; Korica, S. Respiratory diseases of calves on dairy cow farm. Bull. Univ. Agric. Sci. Vet. Med. Cluj-Napoca Vet. Med. 2014, 71, 313-320. [CrossRef]

107. Schwartzkopf-Genswein, K.S.; Booth-McLean, M.E.; McAllister, T.A.; Mears, G.J. Physiological and behavioural changes in Holstein calves during and after dehorning or castration. Can. J. Anim. Sci. 2005, 85, 131-138. [CrossRef]

108. Tunstall, J.; Mueller, K.; Grove, W.D.; Oultram, J.W.H.; Higgins, H.M. Lameness in Beef Cattle: UK Farmers' Perceptions, Knowledge, Barriers, and Approaches to Treatment and Control. Front. Vet. Sci. 2019, 6. [CrossRef] [PubMed]

109. Berry, D.P.; Bermingham, M.L.; Good, M.; More, S.J. Genetics of animal health and disease in cattle. Ir. Vet. J. 2011, 64, 5. [CrossRef] [PubMed]

110. Davis-Unger, J.; Schwartzkopf-Genswein, K.S.G. Prevalence and lameness-associated risk factors in Alberta feedlot cattle. Transl. Anim. Sci. 2019, 3, 595-606. [CrossRef]

111. Blackshaw, J.K.; Blackshaw, A.W. Heat stress in cattle and the effect of shade on production and behaviour: A review. Aust. J. Exp. Agric. 1994, 34, 285-295. [CrossRef]

112. Gaughan, J.B.; Mader, T.L.; Holt, S.M.; Lisle, A. A new heat load index for feedlot cattle. J. Anim. Sci. 2008, 86, 226-234. [CrossRef]

113. Cañas, R.; Quiroz, R.A.; León-Velarde, C.; Posadas, A.; Osorio, J. Quantifying energy dissipation by grazing animals in harsh environments. J. Theor. Biol. 2003, 225, 351-359. [CrossRef]

114. Schwartzkopf-Genswein, K.S.; Stookey, J.M.; Welford, R. Behavior of cattle during hot-iron and freeze branding and the effects on subsequent handling ease. J. Anim. Sci. 1997, 75, 2064-2072. [CrossRef]

115. Coetzee, J.F. A Review of pain assessment techniques and pharmacological approaches to pain relief after bovine castration: Practical implications for cattle production within the United States. Appl. Anim. Behav. Sci. 2011, 135, 192-213. [CrossRef] 
116. Rosvold, E.M.; Kielland, C.; Ocepek, M.; Framstad, T.; Fredriksen, B.; Andersen-Ranberg, I.; Naess, G.; Andersen, I.L. Management routines influencing piglet survival in loose-housed sow herds. Livest. Sci. 2017, 196, 1-6. [CrossRef]

117. Baxter, E.M.; Edwards, S.A. Chapter 3: Piglet mortality and morbidity: Inevitable or unacceptable. In Advances in Pig Welfare; Špinka, M., Ed.; Elsevier: Cambridge, MA, USA, 2018; pp. 73-100. ISBN 9780081010129.

118. Weary, D.M.; Jasper, J.; Hötzel, M.J. Understanding weaning distress. Appl. Anim. Behav. Sci. 2008, 110, 24-41. [CrossRef]

119. Martínez-Miró, S.; Tecles, F.; Ramón, M.; Escribano, D.; Hernández, F.; Madrid, J.; Cerón, J.J. Causes, consequences and biomarkers of stress in swine: An update. BMC Vet. Res. 2016, 12, 171. [CrossRef] [PubMed]

120. Mayorga, J.; Renaudeau, D.; Ramirez, B.; Jason, R.; Baumgard, L. Heat stress adaptations in pigs. Anim. Front. 2018, 9. [CrossRef]

121. Carr, J. Managing Pig Health: A Reference for the Farm, 2nd ed.; 5M Publishing: Sheffield, UK, 2013 ; p. 654. ISBN 9780955501159.

122. Marchant-Forde, J.N. The Welfare of Pigs; Marchant-Forde, J.N., Ed.; Springer: Berlin/Heidelberg, Germany, 2009; ISBN 978-1-4020-8909-1.

123. Nordquist, R.E.; van der Staay, F.J.; van Eerdenburg, F.J.; Velkers, F.C.; Fijn, L.; Arndt, S.S. Mutilating Procedures, Management Practices, and Housing Conditions That May Affect the Welfare of Farm Animals: Implications for Welfare Research. Animals 2017, 7, 12. [CrossRef]

124. Lay, D.C.; Fulton, R.M.; Hester, P.Y.; Karcher, D.M.; Kjaer, J.B.; Mench, J.A.; Mullens, B.A.; Newberry, R.C.; Nicol, C.J.; O’Sullivan, N.P.; et al. Hen welfare in different housing systems. Poult. Sci. 2011, 90, 278-294. [CrossRef] [PubMed]

125. Blokhuis, H.; Arkes, J.G. Some observations on the development of feather-pecking in poultry. Appl. Anim. Behav. Sci. 1984, 12, 145-157. [CrossRef]

126. Blokhuis, H.J. Feather-pecking in poultry: Its relation with ground pecking. Appl. Anim. Behav. Sci. 1986, 16, 63-67. [CrossRef]

127. Blokhuis, H.J. The effect of a sudden change in floor type on pecking behaviour in chicks. Appl. Anim. Behav. Sci. 1989, 22, 65-73. [CrossRef]

128. Whitehead, C.C.; Fleming, R.H. Osteoporosis in cage layers. Poult Sci. 2000, 79, 1033-1041. [CrossRef]

129. Webster, A.B. Welfare implications of avian osteoporosis. Poult. Sci. 2004, 83, 184-192. [CrossRef]

130. Chuppava, B.; Visscher, C.; Kamphues, J. Effect of Different Flooring Designs on the Performance and Foot Pad Health in Broilers and Turkeys. Animals 2018, 8, 70. [CrossRef]

131. Thøfner, I.; Poulsen, L.L.; Bisgaard, M.; Christensen, H.; Olsen, R.H.; Christensen, J.P. Correlation between footpad lesions and systemic bacterial infections in broiler breeders. Vet. Res. 2019, 50, 38. [CrossRef] [PubMed]

132. Gupta, A. Ascites syndrome in poultry: A review. Worlds Poult. Sci. J. 2011, 67, 457-468. [CrossRef]

133. Lara, L.J.; Rostagno, M.H. Impact of Heat Stress on Poultry Production. Animals 2013, 3, 356-369. [CrossRef] [PubMed]

134. Conte, F.S. Stress and the welfare of cultured fish. Appl. Anim. Behav. Sci. 2004, 86, 205-223. [CrossRef]

135. Santos, D.M.S.; Melo, M.R.S.; Mendes, D.C.S.; Rocha, I.K.B.S.; Silva, J.P.L.; Cantanhêde, S.M.; Meletti, P.C. Histological changes in gills of two fish species as indicators of water quality in Jansen Lagoon (São Luís, Maranhão State, Brazil). Int. J. Environ. Res. Public Health 2014, 11, 12927-12937. [CrossRef] [PubMed]

136. Rafatnezhad, S.; Falahatkar, B.; Tolouei, M.H. Effects of stocking density on haematological parameters, growth and fin erosion of great sturgeon (Huso huso) juveniles. Aquac. Res. 2008, 39, 1506-1513. [CrossRef]

137. Ashley, P. Fish welfare: Current issues in aquaculture. Appl. Anim. Behav. Sci. 2007, 104, 199-235. [CrossRef]

138. Rasmussen, R.S.; Larsen, F.H.; Jensen, S. Fin condition and growth among rainbow trout reared at different sizes, densities and feeding frequencies in high-temperature re-circulated water. Aquac. Int. 2007, 15, 97. [CrossRef]

139. Maricchiolo, G.; Mirto, S.; Caruso, G.; Caruso, T.; Bonaventura, R.; Celi, M.; Matranga, V.; Genovese, L. Welfare status of cage farmed European sea bass (Dicentrarchus labrax): A comparison between submerged and surface cages. Aquaculture 2011, 314, 173-181. [CrossRef]

140. Hinchcliff, K.W.; Geor, R.J.; Kaneps, A.J. Equine Exercise Physiology; Saunders Ltd.: Philadelphia PA, USA, 2008; ISBN 978-0-7020-2857-1. 
141. Fsahaye, S.; Kumar, N.; Etsay, K.; Nigussie, A. Health and welfare assessment of working donkeys in and around Rama town, Tigray, Ethiopia. Ethiop. Vet. J. 2018, 22, 26. [CrossRef]

142. Usman, S.; Haimanot, D.; Kabeta, T.; Zenebe, T.; Kebede, G. Health and welfare related assessment of working equine in and Around Batu Town, East Shoa, Central Ethiopia. Nat. Sci. 2015, 13, 1-8.

143. Mellor, D.J.; Beausoleil, N.J. Equine Welfare during Exercise: An Evaluation of Breathing, Breathlessness and Bridles. Animals 2017, 7, 41. [CrossRef] [PubMed]

144. Bihonegn, T.; Bekele, F. Colic in Equine: A review article. Int. J. Adv. Res. Biol. Sci. 2018, 5, 185-195. [CrossRef]

145. McGreevy, P.; Berger, J.; De Brauwere, N.; Doherty, O.; Harrison, A.; Fiedler, J.; Jones, C.; McDonnell, S.; McLean, A.; Nakonechny, L.; et al. Using the Five Domains Model to Assess the Adverse Impacts of Husbandry, Veterinary, and Equitation Interventions on Horse Welfare. Animals 2018, 8, 41. [CrossRef] [PubMed]

146. Chaburte, C.; Endebu, B.; Getahun, F.; Fanta, A.; Assefa, Z.; Aragaw, K. Health and welfare problems of pack donkeys and cart horses in and around Holeta town, Walmara district, Central Ethiopia. J. Vet. Med. Anim. Health 2019, 11, 17-25. [CrossRef]

147. Vucinic, M.; Đorđević, V.; Radisavljevic, K.; Atanasijevic, N.; Nedeljkovic, J. Feeding behavior of stray dogs in a municipal shelter. Acta Vet. 2011, 61, 99-105. [CrossRef]

148. Crispin, S. The Advisory Council on the welfare issues of dog breeding. Vet. J. 2011, 189, 129-131. [CrossRef]

149. German, A. The growing problem of obesity in dogs and cats. J. Nutr. 2006, 136, 1940S-1946S. [CrossRef]

150. Crook, A. Introduction: Pain: An issue of animal welfare. In Pain Management in Veterinary Practice; Egger, C.M., Love, L., Doherty, T., Eds.; John Wiley \& Sons, Inc.: New Delhi, India, 2014. [CrossRef]

151. Broom, D.M. New research relevant to companion animal welfare. Companion Anim. 2015, 20, 548-551. [CrossRef]

152. Intarapanich, N.P.; Touroo, R.M.; Rozanski, E.A.; Reisman, R.W.; Intarapanich, P.P.; McCobb, E.C. Characterization and comparison of injuries caused by spontaneous versus organized dogfighting. J. Am. Vet. Med. Assoc. 2017, 251, 1424-1431. [CrossRef]

153. Mellor, D.J. Tail Docking of Canine Puppies: Reassessment of the Tail's Role in Communication, the Acute Pain Caused by Docking and Interpretation of Behavioural Responses. Animals 2018, 8, 82. [CrossRef] [PubMed]

154. Monath, T.P.; Kahn, L.H.; Kaplan, B. One health perspective. ILAR J. 2010, 51, 193-198. [CrossRef] [PubMed]

155. García, R.; Appleby, M.C.; Scott-Park, F.; Smith, C.W. One Welfare. Vet. Rec. 2015, 179, 629-630.

156. García, R.; Appleby, M.C.; Manteca, X.; Scott-Park, F.; Smith, C.; Velarde, A. One welfare-A platform for improving human and animal welfare. Vet. Rec. 2016, 179, 412-413. [CrossRef]

157. Rojas-Downing, M.M.; Nejadhashemi, P.; Harrigan, T.; Woznicki, S.A. Climate change and livestock: Impacts, adaptation, and mitigation. Clim. Risk Manag. 2017, 16, 145-163. [CrossRef]

158. Steinfeld, H.; Gerber, P.; Wassenaar, T.; Castel, V.; Rosales, M.; de Haan, C. Livestock's Long Shadow: Environmental Issues and Options; Food and Agriculture Organization of the United Nations: Rome, Italy, 2006; ISBN 978-92-5-105571-7.

159. Glatzle, A. Severe methodological deficiencies associated with claims of domestic livestock driving climate change. J. Environ. Sci. Eng. 2014, 2, 586-601.

160. Glatzle, A. Planet at risk from grazing animals? Trop. Grassl.-Forrajes Trop. 2014, 2, 10. [CrossRef]

161. Glatzle, A. Questioning key conclusions of FAO publications 'Livestock's Long Shadow' 2006 appearing again in 'Tackling Climate Change Through Livestock' 2013. Pastor. Res. Policy Pract. 2014, 4, 1. [CrossRef]

162. Gerber, P.J.; Steinfeld, H.; Henderson, B.; Mottet, A.; Opio, C.; Dijkman, J.; Falcucci, A.; Tempio, G. Tackling Climate Change through Livestock A Global Assessment of Emissions and Mitigation Opportunities; Food and Agriculture Organization of the United Nations: Rome, Italy, 2013.

163. Tarazona, A.M.; Ceballos, M.C.; Correa, G.; Cuartas, C.A.; Naranjo, J.F.; Paranhos da Costa, M.J. Welfare of cattle kept in intensive silvopastoral systems: A case report. Rev. Bras. Zootec. 2017, 46, 478-488. [CrossRef]

164. Herrero, M.; Thornton, P.K.; Notenbaert, A.M.; Wood, S.; Msangi, S.; Freeman, H.A.; Bossio, D.; Dixon, J.; Peters, M.; van de Steeg, J.; et al. Smart investments in sustainable food production: Revisiting mixed crop-livestock systems. Science 2010, 327, 822-825. [CrossRef] 
165. Broom, D.M. The scientific basis for action on animal welfare and other aspects of sustainability. In Farming, Food and Nature: Respecting Animals, People and the Environment, 1st ed.; D'Silva, J., McKenna, C., Eds.; Earthscan: London, UK; Routledge: New York, NY, USA, 2018; pp. 93-100. ISBN 9781138541443.

166. Broom, D.M. Components of sustainable animal production and the use of silvopastoral systems. Rev. Bras. Zootec. 2017, 46, 683-688. [CrossRef]

167. Murgueitio, E.; Cuartas, C.A.; Naranjo, J.F. Ganadería del Futuro: Investigation Para El Desarrollo; Fundación CIPAV: Cali, Colombia, 2008.

168. Broom, D.M.; Galindo, F.A.; Murgueitio, E. Sustainable, efficient livestock production with high biodiversity and good welfare for animals. Proc. R. Soc. B 2013, 280. [CrossRef] [PubMed]

169. United Nations. Transforming our World: The 2030 Agenda for Sustainable Development; United Nations: New York, NY, USA, 2015.

170. Keeling, L.; Tunón, H.; Olmos, G.; Berg, C.; Jones, M.; Stuardo, L.; Swanson, J.; Wallenbeck, A.; Winckler, C.; Blokhuis, H. Animal Welfare and the United Nations Sustainable Development Goals. Front. Vet. Sci. 2019, 6, 336. [CrossRef] [PubMed]

(C) 2019 by the authors. Licensee MDPI, Basel, Switzerland. This article is an open access article distributed under the terms and conditions of the Creative Commons Attribution (CC BY) license (http://creativecommons.org/licenses/by/4.0/). 